\title{
STUDY THE PREVALENCE OF PSYCHROTROPHIC FOOD BORNE BACTERIA IN TILAPIA NILOTICA IN DAKAHLIA MARKETS AND ITS EFFECT ON FISH QUALITY
}

\author{
SHEREEN S. MOUSTAFA; HATEM F.A. EL-DOSOKY and AZA. E.A. HASSAN \\ Animal Health Research Institute, Mansoura Branch
}

\begin{abstract}
One hundred samples of Tilabia nilotica were collected from different markets

in Dakahlia Governorate to evaluate their bacteriological quality by determine Psychrotrophic counts. The effect of these foodborne bacteria on chemical quality of fish and consumer health were studied. The bacteriological examination revealed that the mean value of total Psycrotrophic count, total Pseudomonas and total Bacillus cereus count in Tilapia nilotica samples were $3.1 \times 10^{2} \pm 1.8 \times 10^{2} \mathrm{cfu} /$ gram, $5.1 \times 10^{3} \pm 1.4 \times 10^{2} \mathrm{cfu} /$ gram and $4.0 \times 10^{3} \pm 2.6 \times$ $10^{2} \mathrm{cfu} / \mathrm{gram}$ respectively. Biochemical tests as Histamine $(\mathrm{H})$, Thiobarbituric acid (TBA), Total volatile basic amines (TVBN) were measured to determine the quality of examined fish and their effect on health of consumers. The obtained results revealed that, the minimal and maximal histamine $(\mathrm{H})$ content were 5.7 and $24.6 \mathrm{mg} \%$ respectively, $10.2 \& 25.1 \mathrm{mg} / 100 \mathrm{gm}$ for minimal and maximal (TVBN) respectively and $0.534 \& 0.988 \mathrm{mgDK} / \mathrm{Kg}$ for minimal and maximal (TBA) content in examined fish samples
\end{abstract}

Received at 27/2/2013

Key words: Fish -Tilapia nilotica -Bacillus cereus -Pseudomonas - Psychrotrophic

\section{INTRODUCTION}

Fish and fish products were incriminated as a cause of food poisoning, food intoxication as well as many infectious diseases (Lawsan, 1970). The microflora on fish is dominated by psychrotrophic Gram-negative rod shaped bacteria belonging to the genera Pseudomonas, Moraxella, Acinetobacter, Shewanella and Flavobacterium. Members of the Vibrionaceae (Vibrio and Photobacterium) and the Aeromonadaceae (Aeromonas spp.) are also common aquatic bacteria and typical of the fish flora. Grampositive organisms as Bacillus, Micrococcus, Clostridium, Lactobacillus and coryneforms can also be found in varying proportions, but in general, Gram-negative bacteria dominate the microflora. Some psychrotrophic pathogens can grow in refrigerated food with little or no obvious change of sensory characteristics (Berrang et al., 1989) Pseudomonas species and Bacillus cereus are the most predominant psychrotrophic microorganisms and their presence in food creates a great risk as they lead to food poisoning and / or spoilage of food products (Jay, 2000). Also Bacillus cereus causes health hazard to consumers as they cause spoilage and deterioration to meat and meat products and responsible for food poisoning outbreaks (Parry et al., 1993). Bacillus cereus can give rise to two distinct forms of food borne diseases, the emetic form and diarrheal form, the emetic form belived to be associated with an emetic toxin performed in food while diarrheal form is caused by an enterotoxin (Altayer and Sutherland, 2006). From the food safety point of view, proteins as normal conistituent of fish are exposed to degradation by microbial enzymes activity specially proteases (Gill, 1990), Decarboxylation of amino acids histidine is encountered among several species of bacteria including Bacillus cereus and Pseudomonas the significance important of histamine in fish has been discussed by several authors (Vidal-caroa et al., 1990 and Hod \& Khalafalla, 1993). Encountered among several species of bacteria from another point of view we study the effect of psychrotrophic bacteria on the chemical changes of fish, it is well known that both enzymatic and microbiological activity are greatly influenced by temperature. So the aim of this study is the detection of the most common psychrotrophic food borne pathogens in Tilapia nilotica fish samples collected from different markets in Dakahlia Governorate and evaluate their effect on fish quality.

\section{MATERIALS and METHODS}

\section{1 - Collection of samples}

- A total of 100 random fish samples of Tilapia nilotica were collected from fish markets in Dakahlia Governorate.

- Collected samples were transferred in ice box immediately to the laboratory under complete aseptic precautions without delay for bacteriological examination and quality tests. 


\section{2- Preparation of samples for bacteriological} examination:-

- 10 gram of each fish and $90 \mathrm{ml}$ of sterile peptone water were thoroughly mixed by sterile blender for approximately $2.5 \mathrm{~min}$., from which ten fold serial dilutions were prepared.

- The prepared samples were subjected to the following examination:-

a- Determination of psychrotrophic bacterial count (ISO, 2004); using surface spread technique $0.1 \mathrm{ml}$ from each dilution was transferred and evenly spread over a dry surface of previously prepared sterile plate count agar media, allowed to dry for 15 min., inoculated plates divided into two groups each containing one plate from each dilution, the first group incubated at $7^{\circ}$ for 10 days and second incubated at $25^{\circ}$ for $24 \mathrm{hr}$.

- Average number of colonies per gram was determined and the psychrotrophic count / gram was calculated and recorded.

b- Enumeration and identification of Pseudomonas species (ISO, 2004)

- $0.1 \mathrm{ml}$ of each dilution was separately inoculated into duplicated Petri-dishes of Pseudomonas selsctive agar media supplemented with glycerol. The inoculated plates were incubated at $25^{\circ} \mathrm{c}$ for $48 \mathrm{hr}$ after which all developed colonies with greenish yellow pigment were enumerated and the average count / gram was calculated and recorded.

c- Enumeration and identification of Bacillus cereus (ISO, 1987)

- The spreading technique was applied on the surface of Bacillus cereus selective agar media which incubated at $30^{\circ} \mathrm{c}$ for $24 \mathrm{hr}$, then count was recorded. Suspected Colonies were identified by microscopical and biochemical examination.

\section{3- CHEMICAL EXAMINATION OF FISH}

a- Quantitative Assessment of Histamine: was done by using thin layer chromatography method (TLC), (INFO SAMAK, 1989)

b- Determination of total volatile basic nitrogen (TVBN) mg/100gm: It was done according to FAO (1980).

c- Quantitative Assessment of Thiobarbituric acid (TBA) MD/kg:- According to Pikul et al. (1983)

\section{RESULTS}

Table 1: Total Psychrotrophic count, Pseudomonas and Bacillus cereus counts of the examined Tilapia nilotica samples $(n=100)$

\begin{tabular}{lccc}
\hline Bacterial count & Total psychrotrophic & pseudomonas & Bacillus cereus \\
\hline Minimum & $2.0 \times 10^{3}$ & $8.2 \times 10^{2}$ & $7.0 \times 10^{2}$ \\
Maximal & $4.2 \times 10^{4}$ & $2.1 \times 10^{4}$ & $8.2 \times 10^{3}$ \\
Mean & $3.1 \times 10^{2}$ & $5.1 \times 10^{3}$ & $4.0 \times 10^{3}$ \\
Standard error & $1.8 \times 10^{2}$ & $1.4 \times 10^{2}$ & $2.6 \times 10^{2}$ \\
\hline
\end{tabular}

Table 2: Frequency distribution of examined Tilapia nilotica samples based on their total Psychrotrophic \& Pseudomonas and Bacillus cereus count. $(n=100)$ :

\begin{tabular}{lcccccc}
\hline \multirow{2}{*}{ Count } & \multicolumn{2}{c}{ Total Psychrotrophic } & \multicolumn{2}{c}{ Pseudomonas } & \multicolumn{2}{c}{ Bacillus cereus } \\
\cline { 2 - 7 } & No. & $\%$ & No. & \% & No. & \% \\
\hline$<\mathbf{1 0}^{2}$ & 45 & 45 & 40 & 40 & 38 & 38 \\
$\mathbf{1 0}^{\mathbf{2}}<\mathbf{1 0}^{\mathbf{3}}$ & 7 & 7 & 16 & 16 & 22 & 22 \\
$\mathbf{1 0}^{3}<\mathbf{1 0}^{\mathbf{4}}$ & 13 & 13 & 8 & 8 & 40 & 40 \\
$\mathbf{1 0}^{\mathbf{4}}<\mathbf{1 0}^{\mathbf{5}}$ & 35 & 35 & 36 & 36 & 0 & 0 \\
\hline
\end{tabular}

Negative $<10^{2}$ (according to Amal F.A \& Shaboury, 2009) 
Table 3: Results of biochemical examination of fish samples:-

N. of samples $=25$ of each

\begin{tabular}{lccc}
\hline \multicolumn{1}{c}{ Biochemical test } & Minimum & Maximum & Mean \pm S.e \\
\hline $\begin{array}{l}\text { Histamine } \\
\text { Mg\% }\end{array}$ & 5.7 & 24.6 & $11.2 \pm 1.3$ \\
\hline TVB- N mg/100gm & 10.2 & 25.1 & $16.3 \pm 3.2$ \\
\hline TBA mg D M/Kg & 0.534 & 0.988 & $0.701 \pm 0.04$ \\
\hline
\end{tabular}

Table 4: Incidence of Histamine level Histamine, TVB-N and TBA in T. nilotica fish samples in relation to the level pointed by Egyptian standard:

\begin{tabular}{|c|c|c|c|c|c|c|c|}
\hline \multirow[t]{2}{*}{$\begin{array}{l}\text { Kind } \\
\text { fish }\end{array}$} & \multirow[t]{2}{*}{ Biochemical test } & \multirow[t]{2}{*}{$\begin{array}{l}\text { No of } \\
\text { samples }\end{array}$} & \multirow[t]{2}{*}{ Permissible limit } & \multicolumn{2}{|c|}{$\begin{array}{c}\text { Lower than } \\
\text { permissible limit }\end{array}$} & \multicolumn{2}{|c|}{$\begin{array}{l}\text { No higher than } \\
\text { permissible limi }\end{array}$} \\
\hline & & & & No. & $\%$ & No. & $\%$ \\
\hline \multirow{3}{*}{$\begin{array}{l}\text { Tilapia } \\
\text { nilotica }\end{array}$} & -Histamine mg\% & 25 & $10 \mathrm{mg} / 100$ gmuscle & 21 & 84.0 & 4 & 16.0 \\
\hline & -TVB- N mg/100gm & 25 & $25 \mathrm{mg} / 100 \mathrm{gm}$ & 22 & 88.0 & 3 & 12.0 \\
\hline & - TBA mg D M/Kg & 25 & $4.0 \mathrm{mg} \mathrm{DM} / \mathrm{Kg}$ & 25 & 100 & 0 & 0.0 \\
\hline
\end{tabular}

\section{DISCUSSION}

Fish are regarded as being most popular and more perishable than other high protein foods. The flesh of healthy fish is considered bacteriologically sterile, However they are sometimes contaminated with bacterial pathogens and thus can inflect heavy losses in fish all over the world. Fish and fish products were incriminated as a cause of food poisoning, food intoxication as well as many infectious diseases (Lawsan, 1970). The Psychrotrophic bacteria have been received an increased attention by several investigators during recent years due to modern developments in fish production which results in fish must be held for longer period at low temperature before transportation, processing, manufacture or consumption. Psychrotrophes are those organisms that grow well at or below $7^{\circ} \mathrm{c}$ and have their optimum between $20^{\circ} \mathrm{c}-30^{\circ} \mathrm{c}$. Some psychrotrophic pathogens can grow in refrigerated food with little or no obvious change of sensory characteristics (Berrang et al., 1989) Pseudomonas species and Bacillus cereus are the most predominant psychrotrophic micro organisms and their presence in food creates a great risk as they lead to food poisoning and / or spoilage of food products (Jay, 2000). The results in table (1) revealed that the total Psychrotrophic count of examined Tilapia nilotica samples ranged from $2.0 \times 10^{3}$ as a minimum count to $4.2 \times 10^{4}$ as a maximal count with a mean $3.1 \times 10^{2}$ $\pm 1.8 \times 10^{2} \mathrm{SE}$, variable results were reported by (Mousa and Mahmoud, 1997), who recorded that the mean values of total Psychrotrophic count of examined tilapia nilotica was $0.56 \times 10^{2} \pm 0.028 \times$ $10^{2} / \mathrm{g}$. While (Mahmoud, 1994). Recorded that the Mean value was $5.84 \times 10^{3} \pm 0.090$. (Amal F.A El. Shaboury, 2009). mentioned that the total Psychrotrophic count of examined Tilapia nilotica samples ranged from $1.7 \times 10^{3}$ to $3 \times 10^{4}$ with a mean value of $3.2 \times 10^{2} \pm 1.3 \times 10^{2}$. Results in table (2) mentioned that the frequency distributions of total Psychrotrophic count of examined Tilapia nilotica samples were $45 \%$ out of the examined samples considered negative $\left(<10^{2}\right)$. $7 \%$ of samples lied between $10^{2}$ to $<10^{3}, 13 \%$ lied between $10^{3}$ to $<10^{4}$ while the majority of positive samples $(35 \%)$ lied between $10^{4}$ to $<10^{5}$. The obtained results agreed with that mentioned by (Hayes, 1992), and (Amal F.A \& El-Shaboury 2009) as they recorded that the majority of examined Tilapia nilotica samples lied between $10^{4}$ to $10^{5}$. (Lawsan, 1970), stated that fish, fish products were incriminated as acause of food poisoning, food intoxication as well as many infectious diseases. Pseudomonas species and Bacillus cereus are the most predominant Psychrotrophic bacteria which their presence in food creats a great risk as they lead to food poisoning and / or spoilage of food products (Jay, 2000). Pseudomonas species was isolated from fresh water fish by Gram 1993, (Mousa and Mahmoud, 1997), in this study results in table (1) mentoned that the minimum Pseudomonas species count of examined Tilapia nilotica samples was $8.2 \times$ $10^{2} \&$ maximal count was $2.1 \times 10^{4}$ with means count of $5.1 \times 10^{3} \pm 1.1 \times 10^{2}$. Lower Pseudomonas count 
was recorded by (Lamada - Hanan, 1999), but this above results agreed with that recorded by (Amal F.A and El-Shaboury, 2009) as they recorded that the mean value of pseudomonas count in the examined Tilapia nilotica samples was $4.5 \times 10^{3}$. The frequency distribution of examined tilapia nilotica samples based on their pseudomonas count was recorded in table (2) and revealed that the majority of samples lied between $10^{4}<10^{5}$ with the percentage of $36 \%$ from total examined tilapia nilotica samples, a same results were recorded by (Hassan 1991 and Amal F.A \& El- Shaboury 2009). Bacillus cereus was widely distributed in nature, water, soil, air and can be isolated from a wide variety of foods, (Parry et al., 1993) mentioned that Bacillus cereus cause health to consumers and also responsible for food poisoning outbreaks. The results in table (1) illustrated that the minimal Bacillus cereus count of examined Tilapia nilotica samples was $7.0 \times 10^{2}$, maximal was $8.2 \times$ $10^{3}$ with mean value $4.0 \times 10^{3} \pm 2.6 \times 10^{2}$. The frequency distribution of Bacillus cereus count in tilapia nilotica samples was recorded in table (2) which revealed that the majority of samples lied between $10^{3}<10^{4}$, a resembling results were mentioned by (Amal F.A \& El-Shaboury, 2009). In this study the quality outlines of examined Tilapia nilotica were detected by determining the effect of Psychrotrophic bacteria on biochemical characters of examined fish, a quantitative assessment of Histamine (H), Total volatile basic nitrogen (TVBN) and Thiobarbituric acid (TBA) was made to determine the effect of Pseudomonas species and Bacillus cereus on fish quality. Results in table (3) revealed that minimal and maximal level of histamine were 5.7 and 24.6 $\mathrm{mg} \%$ with11.2 $\pm 1.3 \mathrm{SE}$ mean value respectively, these were nearly in agreement with results registered by (Park et al., 1980), (Vidal -Caroa et al., 1990); (Hoda, H.A. and Khalafala, 1993), as they recorded that histamine level in naturally spoiled fish ranged from $22 \mathrm{mg} / \mathrm{Kg}$ up to $25 \mathrm{mg} / \mathrm{kg}$. (Hosseini et al., 2009) mentioned that histamine amounts depend on production date of samples.Table 3 showed that minimal and maximal values of TVBN were 10.2 \& $25.1 \mathrm{mg} / 100 \mathrm{gm}$ respectively with a mean value 16.3 $\pm 3.2 \mathrm{mg} / 100 \mathrm{gm}$ these results with in agreement with (Acuff et al., 1984). Increasing of TVBN during storage indicated possible spoilage of fish, such increase may be attributed to the production of volatile basic compound such as ammonia as reported by (Putro et al., 1985; Galli et al., 1993). Also table (3) revealed that the minimal and maximal thiobarbituric acid (TBA) values of examined fish samples were $0.534 \mathrm{mg} \mathrm{MD} / \mathrm{Kg}$ and $0.988 \mathrm{mg}$ $\mathrm{MD} / \mathrm{Kg}$ with a mean value $0.701 \pm 0.04 \mathrm{mg} \mathrm{DM} / \mathrm{Kg}$ and these results were in agreement with (Undeland and Lingnert 1999). However these results were lower than (Sohad et al., 2008) who recorded an increase in thiobarbituric acid value (TBA). From all above results fresh fish should be consumed as soon as possible and surely within 3 days from purchased as recorded by (Ahmed and Yassien 2000), because of longer storage may result in rapid rise in histamine content, volatile nitrogen basic compound and thiobarbituric acid. Also growth of Psychrotrophic bacteria in fish has become a significant problem due to wide spread use of refrigerated storage of fish, that cause a potential threat to consumers health. According to the results recorded in table (4), Histamine, TVBN and TBA, were higher than the permissible limits obtained by Egyptian standard (2005) with percentages 16.0, 12.0 and 0.0. respectively.

\section{REFERENCES}

Acuff, G.; Izat, A.L. and Finne, G. (1984): Microbial flora of readed tilapia held on ice. J. Food. Prot., 47: 778-780.

Ahmed, A.M. and Yassien, M.A (2000): Level of histamine-forming bacteria in fish from Ismailia markets with records of scombroid poisoning in children. S.C.V. M.J., ш (1).

Altayer, M. and Sutherland, A.D. (2006): Bacillus cereus is a common in the environment but emetic toxin producing isolates are rare. J. Appl. Microbiology, 100 (1): 7-14.

Amal, F.A. Mansour and EL-Shaboury, F.A. (2009): Prevalence of psychrotrophic foodborne pathogens in fish in Alexandria markets. Assiut Vet. Med. J. Vol. 55. No. 121 April 2009.

A.P.H.A (American Public Health Association) (1984): compendium of Methods for Microbiological Examination of foods. $3^{\text {ed }} \mathrm{Ed}$. Washington, D.C.

Berrang, M.E.; Brachett, R.E. and Beuchat, L.R. (1989): Groth of listeria monocytogenes on fresh vegetables stored under a controlled atmosphere. J. Food prot. (52): 702-705.

Campton, R. (1981): In Campton Encyclobedia vol. 5 pp. 601. Publisher University of Chicago VSA.

FAO (1980): Manualof Food Quality Comtrol. IV. Microbiological analysis. FAO United Nations, Rome. Tech. Res. Ser.

Galli, A.I.; Franzetti, S.; Carelli, L.; Piergiovanni, I. and Fava, P. (1993): Microbiological quality and shelf life of chilled cod fillets in Vacuum skin and modified armosphere packaging. Pack. Technol. Sci., 6: 147-154.

Hassan, M.T. (1991): Microbiological status of frozen dressed fish. M.V.SC Thesis Fac. Vet. Med., Moshtohor, Zagazig Univ. - Banha.

Hayes, P.R. (1992): Food Microbiology and Hygiene. Elsevier science publishers (L.T.d).

Hoda, H. Awad and Khalafalla, F. (1993): Histamine level in imported scombroid fishes. Vet. Med. J., Giza 41, 3: 67- 71.

Hosseini, H.; Dolatabadi, R.; Shekarchi, M.; Keshavarz, A.; Eskanadari, S. and PiraliHamedani, M. (2009): Evaluation of histamine 
in canned tuna fish post market samples in Iran using Elisa Asian J. of Chemistry. 21, 8: 6429-6434.

ICSMF (International commission on Microbiological specification for foods) (1978): Their significance and methods of enumeration. $2^{\text {nd }}$ Ed. Univ. of Toronto press. Toronto - buffalo, Canda.

INFO SAMAK/UNDP/FAO (1989): Training course on fish processing technology and quality control. Cairo, Egypt, 28 January -15 February.

ISO (1987): Microbiology general guidance for enumeration of Bacillus cereus. ISO 7932. Geneva, Switzerlan.

ISO 7932 (2004): Microbiology of food and animal feeding stuffs, Horizontal methods for enumeration of presumptive Bacillus cereus colony count technique at 30 dgree c.

Jay M.T. (2000): Modern Food microbiology. Sixth Ed. Gaithersburg. Maryland.

Lamada-Hana, M.O. (1999): Chemical and sensory changes associated with microbial flora of Miditerranean boque (Boops -boops) stored aerobically at $0,3,7$ and $10^{\circ}$. Appl. Environ. Microb. 65 (2): 698.

Lawsan, T.B. (1970): Some aspects of fish inspection and public health Vet. Reas., 87: 52.

Mahmoud, Y.E. (1994): Studies on frozen fish. Ph. D. thesis, Fac. Vet. Med. Moshtoher, Zagazig University. Benha.
Mousa, M.M. and Mahmoud, Y.E. (1997): Hygenic quality of newly caught fresh fish. Assuit. Vet. Med. J. 219-223.

Park, Y.H.; Kim, D.S. and Kim, S.B. (1980): Changes in histamine content in muscle of dark fleshed fish during storing and processing. Bull. Korean fish Soc., 13: 15-22.

Parry, J.M.; Turnbull, P.C.B. and Gibson, J.R. (1993): Colour Atlas of Bacillus species, Wolf Medical Publication Ltd. London.

Pikul, J.; Leszezynski, D.E. and Kummerow, F. (1983): Elimination of sample autoxidation by butylatedhydroxyl tolune. J. Agric. Food Chem. 31: 1338.

Putro, S.; Saleh, M. and Bandolutmoto, B.S. (1985): Storage life of rabbit during icing. FAO Fisheries. Rep., Np 317 (suppl.), 54: 61.

Sohad, H.E.; EL. Leboudi, Nahed; Salem, I.F. and Heikal, G.I. (2008): Bacterial and chemical evaluation of some imported frozen fish in Kafer-El-Sheikh Governorate markets. J. Egypt. Vet. Med. Assoc. 68, 3: 119-128.

Undeland, I. and Lingnert, H. (1999): Lipid oxidation in fillets of herring (Glupea harengus) during frozen storage. J. of Agr. and Food Chemi., 47: 275-279.

Vidal-Caroa, M.C.; Maria, T.V. and Font, A.M. (1990): Spectrofluorometric determinate of histamine in fish and meat products. J. Assoc. of Anal. Chem., 73, 4: 565-567.

\section{دراسة مدى تواجد البكتريا الممرضة المحبة للبرودة فى اسماك البلطى النيلى فى اسواق محافظة الدقهلية

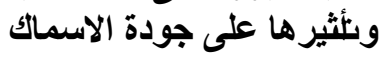

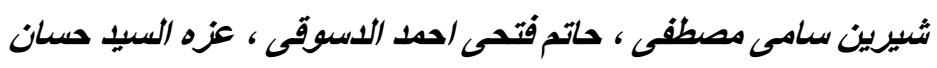

تم جمع عدد 100 عينة من اسماك البلطى النيلى من اسو اق محافظة الدقهلية وذللك لتقييمها من الناحية الصحية ودر اسة مدى تو اجد الدئ

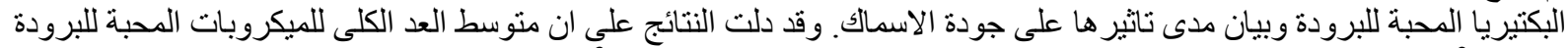

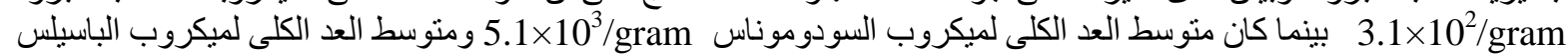

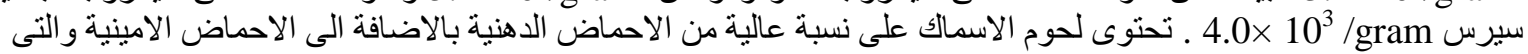

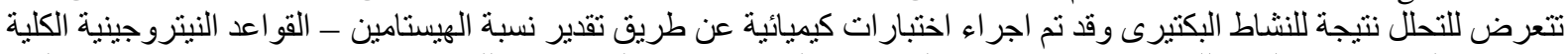

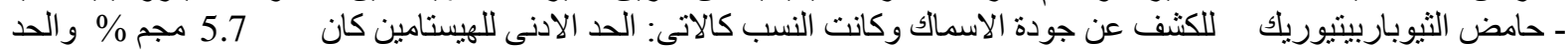

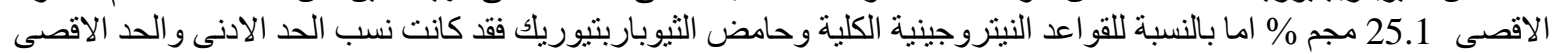

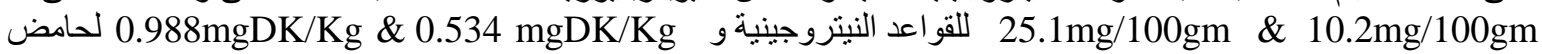
الثيوباربنيوريك. 